\title{
Dantrolene inhibits nitric oxide synthase in rat alveolar macrophages treated with lipopolysaccharide and interferon- $\gamma$
}

\author{
Chi-Yuan Li MD MS, * \\ Tz-Chong Chou PhD, ${ }^{\dagger}$ \\ Chin-Chen Wu PhD, \\ Chih-Shung Wong MD PhD, * \\ Shung-Tai Ho MD, * \\ Mao-Hsiung Yen $\mathrm{PhD}, \mp$ \\ Yu-An Ding MD PhD $\$$
}

Purpose: To examine the effects of dantrolene on nitric oxide $(\mathrm{NO})$ production and on the activity and protein expression of inducible nitric oxide synthase (iNOS) induced by lipopolysaccharide (LPS) plus interferon- $\gamma$ (IFN $\gamma$ ) in rat alveolar macrophages.

Methods: Pulmonary alveolar macrophages isolated from Sprague-Dawley rats were used. After incubation of macrophages with dantrolene $(\mid$ to $100 \mu \mathrm{M})$ and LPS $\left(\mid \mu \mathrm{g} \cdot \mathrm{ml}^{-1}\right)$ and IFN- $\gamma\left(100 \mathrm{u} \cdot \mathrm{ml}^{-1}\right)$ for $24 \mathrm{hr}$, the cell-free medium was removed for measuring the nitrite and tumour necrosis factor- $\alpha$ (TNF- $\alpha$ ) levels by Griess reaction and ELISA kit, respectively. The harvested macrophages were also used to determine the activity of iNOS by using the conversion of $\left[{ }^{3} \mathrm{H}\right]$ - L-arginine to $\left[{ }^{3} \mathrm{H}\right]$ - L-citrulline method. Protein expression of iNOS was detected by Western blot analysis.

Results: In rats alveolar macrophages, (I) dantrolene (I to $100 \mu \mathrm{M}$ ) caused a dose-dependent suppression of the production of nitrite and TNF- $\alpha$ induced by LPS $\left(1 \mu \mathrm{g} \cdot \mathrm{ml}^{-1}\right)$ plus IFN- $\gamma\left(100 \mathrm{u} \cdot \mathrm{ml}^{-1}\right)$ and (ii) dantrolene $(100 \mu \mathrm{M})$ inhibited the activity (by $37 \pm 5 \%, P<0.01$ ) and protein expression (by $39 \pm 12 \%, P<0.01$ ) of iNOS in response to LPS plus IFN- $\gamma$.

Conclusion: Dantrolene inhibits NO production as well as the activity and expression of iNOS in alveolar macrophages treated with LPS plus IFN- $\gamma$, which may be associated with the reduction of TNF- $\alpha$ production.

Objectif : Évaluer les effets du dantrolène sur la production d'oxyde nitrique (NO) et sur l'activité et l'expression protéique de l'enzyme inductible synthétase de l'oxyde nitrique (iNOS) tel qu'induit par une lipopolysaccharide (LPS) associée à l'interféron- $\gamma$ (IFN- $\gamma$ ) chez des macrophages alvéolaires de rat.

Méthodes : Des macrophages alvéolaires pulmonaires isolés chez des rats Sprague-Dawley ont été utilisés. Après incubation durant $24 \mathrm{~h}$ des macrophages avec du dantrolène $(1-100 \mu \mu \mathrm{m})$, de la LPS $\left(1 \mu \mathrm{g} \cdot \mathrm{ml}^{-1}\right)$ et de l'IFN- $\gamma\left(1 \mu \cdot \mathrm{ml}^{-1}\right)$, le liquide d'incubation a été retiré pour mesurer les nitrites et le facteur de nécrose tumorale- $\alpha$ (TNF- $\alpha$ ) par la réaction de Griess et un kit Elisa, respectivement. Les macrophages récoltés après incubation ont aussi été utilisés pour déterminer l'activité de iNOS par la méthode utilisant la conversion de la ${ }^{3} \mathrm{H}$-L-arginine en ${ }^{3} \mathrm{H}$ - L-citrulline. L'expression protéique de iNOS a été détectée par l'analyse Westem blot.

Résultats : Chez des macrophages alvéolaires de rat, le dantrolène (1-100 $\mu \mathrm{m})$ cause une suppression proportionnelle à la dose de la production des nitrites et du TNF- $\alpha$ induit par LPS plus IFN- $\gamma$; le dantrolène ( 100 $\mu \mathrm{m}$ ) inhibe aussi l'activité (par $37 \pm 5 \%, P<0,01$ ) et l'expression protéique (par $39 \pm 12 \%, P<0,01$ ) de iNOS en réponse à $L P S$ plus IFN- $\gamma$.

Conclusion : Le dantrolène inhibe la production de NO ainsi que l'activité et l'expression de iNOS chez des macrophages alvéolaires traités avec LPS associé à IFN- $\gamma$, et ceci pourrait être associé à la réduction de la production de TNF- $\alpha$.

From the Departments of Anesthesiology, ${ }^{\star}$ Graduate Institute of Medical Sciences, ${ }^{\dagger}$ Pharmacology, ${ }^{\ddagger}$ Tri-Service General Hospital, National Defense Medical Center; and Cardiology, Veterans General Hospital, $\$$ Taipei, Taiwan, Republic of China.

Address correspondence to: Dr. Chi-Yuan Li, Department of Anesthesiology, 8, Sec 3, Ting-Chow Rd, Taipei, Taiwan, Republic of

China. Phone: 886-2-365-0729; Fax: 886-2-365-4670; E-Mail: cyli@ndmcl.ndmctsgh.edu.w

Accepted for publication December 17, 1997.

Supported by a grant of the Tri-service General Hospital, Taipei, Taiwan, R.O.C. (TSGH-C87-49). 


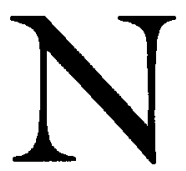

ITRIC Oxide (NO) is a potent, endogenous vasodilator, produced from the quanidino nitrogen group of $\mathrm{L}$-arginine by the action of the enzyme nitric oxide synthase (NOS). ${ }^{1}$ Three different isoforms of NOS have been isolated, cloned, sequenced and expressed. ${ }^{2,3}$ The endothelial and neuronal types of NOS are calcium-dependent, expressed constitutively, and mediate many physiological responses. The inducible NOS (iNOS), whose synthesis is induced in macrophages, hepatocytes, and vascular smooth muscle cells by endotoxin (lipopolysaccharide, LPS) and several cytokines (e.g., tumour necrosis factor- $\alpha$, TNF- $\alpha$; interleukin-l; interferon- $\gamma$, IFN- $\gamma$ ), is a calcium-independent enzyme and is expressed only under pathological conditions. ${ }^{1}$ Either IFN- $\gamma$ plus TNF- $\alpha$ or IFN- $\gamma$ plus LPS can interact synergistically to induce NO release and iNOS expression. ${ }^{4,5}$ Once iNOS is activated, iNOS continuously releases large amount of NO. Nitric oxide is also a cytotoxic molecule which kills bacteria and tumour cells. Stimulation of the synthesis of iNOS isoform in macrophage is thought to play a key role in host defence and immunological function. ${ }^{6}$

Enhanced formation of NO following the induction of iNOS contributes importantly to the circulatory failure (hypotension, vascular hyporeactivity to vasoconstrictor agents, myocardial dysfunction and maldistribution in organ blood flow) in circulatory shock of various etiologies. ${ }^{7}$ Inducible NOS is different from other isoforms for its activation is independent of changes in cytosolic free $\mathrm{Ca}^{2+}$. However, Park et al. have demonstrated that a rapid increase in cytosolic free $\mathrm{Ca}^{2+}$ is associated with the induction of iNOS in murine peritoneal macrophages. They suggested that the induction, but not the activity, of iNOS is dependent on free cytosolic $\mathrm{Ca}^{2+}$ level. ${ }^{8}$ Indeed, several different $\mathrm{Ca}^{2+}$ channel antagonists protect against cardiovascular failure and prolong survival time in various models of endotoxin shock. ${ }^{9-11}$

Dantrolene is a drug that is remarkably effective in virtually eliminating mortality in patients with the highly lethal malignant hyperthermia syndrome, a disorder characterised by an increased calcium influx due to defective handling of $\mathrm{Ca}^{2+}$ by the sarcoplasmic reticulum. ${ }^{12}$ In addition, dantrolene inhibits the release of calcium from the sarcoplasmic reticulum then to reduce free cytosolic $\mathrm{Ca}^{2+}$ concentration. ${ }^{13-14}$ Recently, it has been proposed that intracellular free calcium plays an important role in the metabolic abnormalities during sepsis. ${ }^{15}$ Moreover, several studies have demonstrated that dantrolene attenuates the delayed circulatory failure, and improves the survival in a murine model of severe septic shock. ${ }^{16,17}$ The ben- eficial effects of dantrolene in septic shock may be attributed to a reduction of TNF- $\alpha$ and iNOS induction caused by endotoxin. However, no direct evidence has showed that dantrolene inhibits the induction of iNOS in tissues or cells from endotoxaemic animals. Therefore, we examined the effect of dantrolene on NO and TNF- $\alpha$ production as well as the activity and protein expression of inducible nitric oxide synthase (iNOS) induced by LPS plus IFN- $\gamma$ in rat alveolar macrophages.

\section{Methods \\ Preparation of macrophages}

This study was approved by our Institutional Animal Care and Use Committee. Adult male Sprague-Dawley rats $(300-400 \mathrm{~g})$ were deeply anaesthetised with an overdose of sodium pentobarbitone $\left(75 \mathrm{mg} \cdot \mathrm{kg}^{-1}, i p\right)$. The trachea was exposed and cannulated with a catheter. The lungs were each gently lavaged with $5 \mathrm{ml}$ cold phosphate buffer solution (PBS) $\left(4^{\circ} \mathrm{C}\right)$ five-six times. Each experiment was performed on macrophages lavaged from $9-10$ rats (i.e., $\mathrm{n}=1$ ). The combined lavage fluid from those rats was centrifuged at $200 \mathrm{~g}$ for five minutes at $4^{\circ} \mathrm{C}$. The supernatant was discarded, and the macrophages were resuspended in 24-well plates $\left(5 \times 10^{5}\right.$ cells per well) (Costar, Cambridge, MA) at $0.6 \mathrm{ml}$ per well in RPMI 1640 (Gibco, Grand Island, NY) with $10 \%$ heat-inactivated fetal bovine serum (JRH Biosciences, Lenexa, $\mathrm{KS})$, penicillin $\left(100 \mathrm{U} \cdot \mathrm{ml}^{-1}\right)$ and streptomycin (100 $\left.\mathrm{mg} \cdot \mathrm{ml}^{-1}\right)$. After three hours incubation, unattached macrophages were removed. The fresh medium either containing $E$. coli LPS $\left(1 \mu \mathrm{g} \cdot \mathrm{ml}^{-1}\right)$ (Sigma, serotype No. 0127-B8) and IFN- $\gamma\left(100 \mathrm{u} \cdot \mathrm{ml}^{-1}\right)$ alone or with dantrolene ( 1 to $100 \mu \mathrm{M}$ ) (Sigma, St. Louis, $\mathrm{MO}$ ) was added then incubated at $37^{\circ} \mathrm{C}, \mathrm{CO}_{2}$ $\mathbf{5 \%}$ in humidified air for $24 \mathrm{hr}$. Because dantrolene is poorly soluble in aqueous media, we used dimethylsulfoxide (DMSO) as a solvent. The final concentration of DMSO is $0.5 \%$ in all the medium including control and LPS plus IFN- $\gamma$ treated alone group.

After $24 \mathrm{hr}$ incubation, an aliquot of the conditioned medium was removed for assays of nitrite and TNF- $\alpha$. The macrophages were washed and scraped into cold PBS, and were centrifuged at $200 \mathrm{~g}$ for five minutes at $4^{\circ} \mathrm{C}$. The cell pellet was frozen at $-70^{\circ} \mathrm{C}$ for later processing or resuspended in $250 \mu$ sonication buffer Tri$\mathrm{HCl}(50 \mathrm{mM}, \mathrm{pH} 7.4)$ containing EDTA $(0.1 \mathrm{mM})$, EGTA $(0.1 \mathrm{mM})$ and phenylmethylsulphonyl-fluoride ( $1 \mathrm{mM}$ ) at $4^{\circ} \mathrm{C}$. The cell pellet was disrupted by sonication (Heat systems, Inc. Famingdale, NY) four times for $10 \mathrm{sec}$ in $\mathbf{5 0 \%}$ duty cycle. An aliquot of the whole lysate was centrifuged at $10,000 \mathrm{~g}$ for two minutes at $4^{\circ} \mathrm{C}$. The supernatant was collected for the determina- 
tion of iNOS activity and protein expression. The protein content was measured by the Biorad protein assay method.

\section{Measurement of nitrite and TNF- $\alpha$}

Accumulated nitrite levels were determined by mixing $100 \mu \mathrm{l}$ of cell culture medium with $100 \mu \mathrm{l}$ of Griess reagent (sulphanilamide $1 \%$ and $\mathrm{N}$-(1-naphthyl)-ethylene diamide $0.1 \%$ in phosphoric acid $5 \%$ ), incubating the mixture for $15 \mathrm{~min}$ at room temperature. The absorbance was measured at $550 \mathrm{~nm}$ using a MRX microplate reader (Dynatech, Guernsey, UK). Solutions of $\mathrm{NaNO}_{2}(1-100 \mu \mathrm{M})$ diluted in culture medium were used as standards. The amounts of TNF- $\alpha$ in the cultured medium were measured by a rat TNF- $\alpha$-ELISA kit (Genzyme Corporation, Cambridge, MA). The minimal detection limits of this assay is $10 \mathrm{pg} \cdot \mathrm{ml}^{-1}$. The specificity of the TNF- $\alpha$ kit shows no cross-reactivity with other cytokines even with the highest concentration $1 \mu \mathrm{g} \cdot \mathrm{ml}^{-1}$.

\section{NOS activity assay}

Nitric oxide synthase activity was determined by measuring the conversion of $\left[{ }^{3} \mathrm{H}\right]-\mathrm{L}$-arginine to $\left[{ }^{3} \mathrm{H}\right]-\mathrm{L}$ citrulline as previously described. ${ }^{18}$ The supernatant (20 $\mu \mathrm{l}$, approximately $60 \mu \mathrm{g}$ protein) was incubated in HEPES buffer $(20 \mathrm{mM}, \mathrm{pH} 7.5)$ containing L-arginine $(10 \mu \mathrm{M})$ and $\left[{ }^{3} \mathrm{H}\right]$ - L-arginine $\left(3 \mu \mathrm{Ci} \cdot \mathrm{ml}^{-1}\right)$, L-valine (60 mM), NADPH (1 mM), calmodulin (30 nM), tetrahydrobiopterin $(5 \mu \mathrm{M})$ and calcium $(2 \mathrm{mM})$ for 20 $\mathrm{min}$ at $25^{\circ} \mathrm{C}$. The reaction was stopped by adding $1 \mathrm{ml}$ ice-cold HEPES buffer ( $\mathrm{pH}$ 5.5) containing EGTA $(2 \mathrm{mM})$ and EDTA $(2 \mathrm{mM})$. The reaction mixture was applied to Dowex 50W $\left(\mathrm{Na}^{+}\right.$form) columns. This resin allows citrulline (neutral amino acid) to elute while arginine (cationic $[+]$ charge) is bound. Columns were then rinsed with $2 \times 1 \mathrm{ml} \mathrm{HEPES} \mathrm{buffer} \mathrm{(} \mathrm{pH} 5.5$ ) to ensure complete elution of citrulline. The amount of $\left[{ }^{3} \mathrm{H}\right]-\mathrm{L}$ citrulline eluted was quantified by liquid scintillation spectroscopy (Beckman, LS3801, Orange county, CA) with an efficiency of $90-94 \%$. The activity of NOS is expressed as pmol of $\left[{ }^{3} \mathrm{H}\right]$-L-citrulline produced per $\mathrm{mg}$ of protein. Experiments performed in the absence of NADPH were to determine the extent of $\left[{ }^{3} \mathrm{H}\right]$ - $\mathrm{L}$-citrulline formation of independent of NOS activity. The activity of the $\mathrm{Ca}^{2+}$-independent iNOS activity was determined from the difference between samples containing $2 \mathrm{mM}$ EGTA and samples without NADPH.

\section{Western blotting}

Cell lysate containing $2 \mu \mathrm{g}$ protein was denatured and an equal amount of protein loaded on SDS-PAGE $7.5 \%$ gel using PhastSystem with PhastGel (Pharmacia Biotech,
Uppsala, Sweden). Separated proteins were transferred to nitrocellulose membranes using PharmTransfer Semi-Dry transfer kit (Pharmacia Biotech, Uppsala, Sweden). The membranes were blocked with BSA $1 \%$ in Tris-buffer solution (TBS) $\mathrm{pH}=8.0$ containing Tween $-200.1 \%$ for two hours at room temperature and then incubated with mouse monoclonal anti-iNOS antibody (1:2000 dilution, Transduction Laboratories, Lexington, KY) in TBS containing Tween-20 $0.1 \%$ for $12 \mathrm{hr}$ at $4^{\circ} \mathrm{C}$. The membrane was washed and finally incubated with a 1:1000 dilution of anti-mouse IgG conjugated to horseradish peroxidase for two hours at room temperature. After successive washes with TBS, the immunocomplexs were detected using an enhanced horseradish peroxidase/luminol chemiluminescence reaction (Amersham International plc, Buckinghamshire, UK) and exposed to X-ray film for two-three minutes. The relative expression of iNOS protein in cell lysate was quantified by densitometric scanning of the Western blots using Image-pro plus software.

\section{Cell respiration}

Cell respiration, an indicator of cell viability, was assessed by mitochondria-dependent reduction of MTT [3-(4,5-dimethylthiazol-2-yl)-2.5-diphenyltetrazolium bromide] to formazan. ${ }^{19}$ After incubating with either the LPS $\left(1 \mu \mathrm{g} \cdot \mathrm{ml}^{-1}\right)$ plus IFN- $\gamma\left(100 \mathrm{u} \cdot \mathrm{ml}^{-1}\right)$ alone or with various concentration of dantrolene $(1-100 \mu \mathrm{M})$ in DMSO for $24 \mathrm{hr}$, cells were incubated with MTT in a concentration of $0.3 \mathrm{mg} \cdot \mathrm{ml}^{-1}$ for two hours at $37^{\circ} \mathrm{C}$. Cultured medium was removed by aspiration and cells were treated with DMSO for $30 \mathrm{~min}$. The plates were read on a MRX spectrophotometer (Dynatech, Guernsey, UK) at a wavelength of $550 \mathrm{~nm}$.

\section{Statistics}

Data are reported as mean $\pm S E M$. Data were analysed by using one-way analysis of variance (ANOVA) followed by a multiple comparison test (Scheffes test).

\section{Results}

Effects of dantrolene on the nitrite and TNF- $\alpha$ production Activation of alveolar macrophages with LPS $\left(1 \mu \mathrm{g} \cdot \mathrm{ml}^{-1}\right)$ plus IFN- $\gamma\left(100 \mathrm{u} \cdot \mathrm{ml}^{-1}\right)$ resulted in an increase in nitrite and TNF- $\alpha$ levels in the medium from $1.4 \pm 0.3 \mu \mathrm{M}$ and $0.22 \pm 0.02 \mathrm{ng} \cdot \mathrm{ml}^{-1}$ (i.e., without LPS and IFN- $\gamma$ ) to $38.1 \pm 3.3 \mu \mathrm{M}$ and $6.44 \pm 0.39 \mathrm{ng} \cdot \mathrm{ml}^{-1}$ after $24 \mathrm{hr}$, respectively $(P<0.01)$. Administration of the macrophages with dantrolene ( 1 to $100 \mu \mathrm{M}$ ) reduced the increment of nitrite and TNF- $\alpha$ levels in a concentrationdependent manner (see Figures 1, 2). However, dantrolene did not affect the viability of alveolar macrophages (as determined by the MTT assay) when given alone or combination with LPS plus IFN- $\gamma$ (data not shown). 


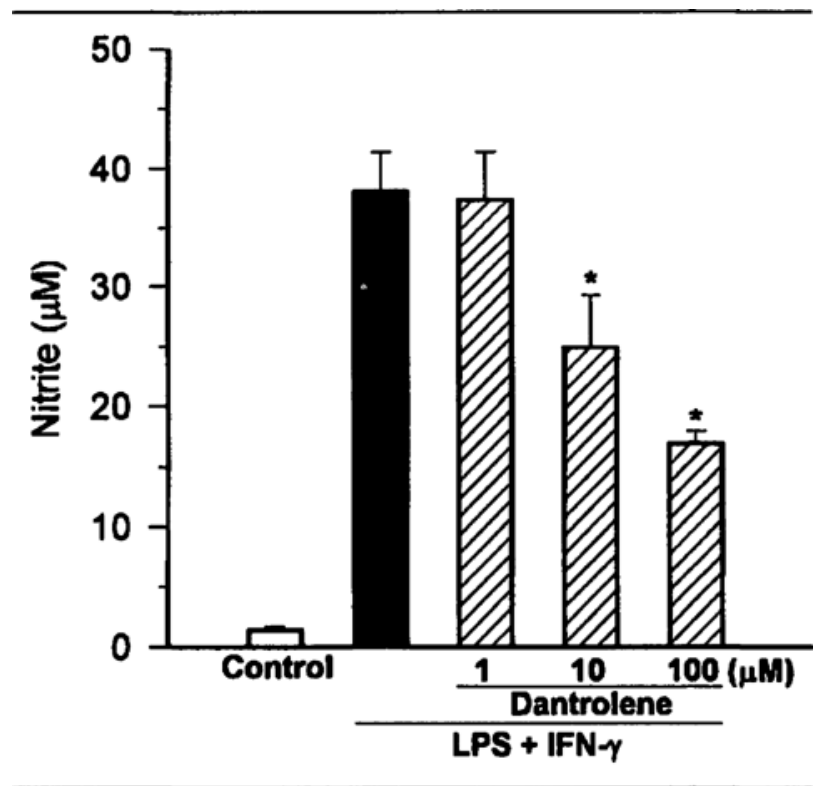

FIGURE 1 Dantrolene causes a concentration-dependent inhibition of nitrite formation induced by LPS plus IFN- $\gamma$ in rat alveolar macrophages. Values are expressed as mean \pm SEM of 10-12 observations from three experiments

$\left({ }^{*} P<0.01\right.$ vs LPS plus IFN- $\gamma$ alone).

Note that nitrite formation induced by LPS plus IFN- $\gamma$ was increased when compared with the control.

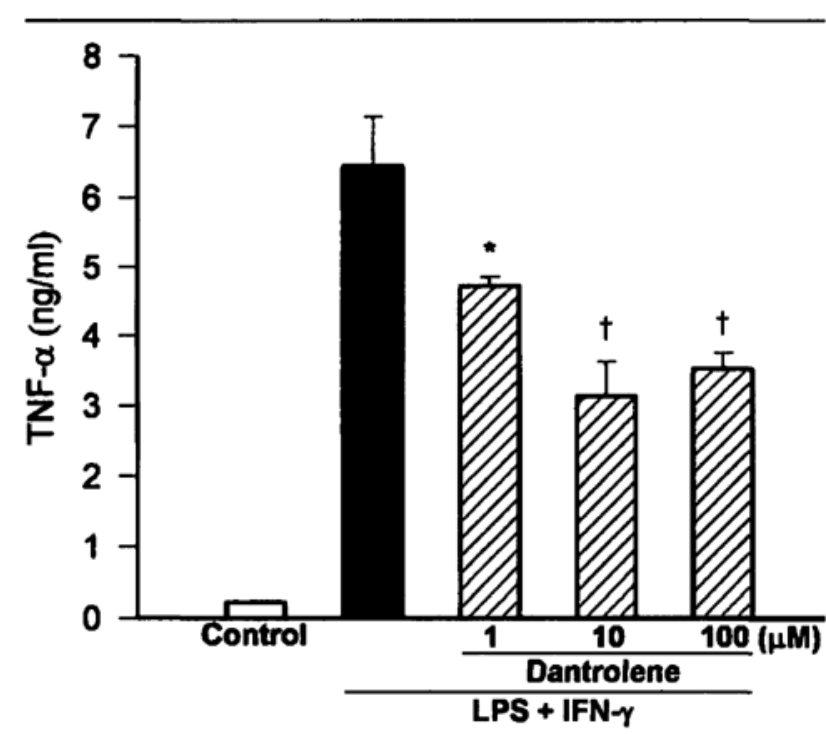

FIGURE 2 Dantrolene causes a concentration-dependent inhibition of TNF- $\alpha$ production induced by LPS plus IFN- $\gamma$ in rat alveolar macrophages. Values are expressed as mean \pm SEM of 10-12 observations from three experiment

${ }^{*} P<0.05$

${ }^{\dagger} P<0.01 v s$ LPS plus IFN- $\gamma$ alone.

Note that TNF- $\alpha$ production induced by LPS plus IFN- $\gamma$ was increased when compared with the control.
Effects of dantrolene on iNOS activity.

After incubating alveolar macrophages with LPS $\left(1 \mu \mathrm{g} \cdot \mathrm{ml}^{-1}\right)$ and IFN- $\gamma\left(100 \mathrm{u} \cdot \mathrm{ml}^{-1}\right)$ for $24 \mathrm{hr}$, the iNOS activity was increased from $3.4 \pm 0.9$ (i.e., untreated alveolar macrophages) to $68.3 \pm 2.8 \mathrm{pmol} \cdot \mathrm{min}^{-1} \cdot \mathrm{mg}^{-1}$ protein. Co-treatment of macrophages with dantrolene $(100 \mu \mathrm{M})$ and LPS plus IFN- $\gamma$ caused a reduction in iNOS activity $(P<0.01 ; v s$ LPS plus IFN- $\gamma$ alone) (Figure 3).

\section{Effects of dantrolene on iNOS expression}

The basal iNOS protein expression was almost undetectable by Western blot analysis in pulmonary alveolar macrophages without the challenge of LPS plus IFN- $\gamma$ (Figure 4). After stimulating macrophages with LPS $\left(1 \mu \mathrm{g} \cdot \mathrm{ml}^{-1}\right)$ plus IFN- $\gamma\left(100 \mathrm{u} \cdot \mathrm{ml}^{-1}\right)$ for $24 \mathrm{hr}$, the iNOS expression increased almost five times of basal level. At $100 \mu \mathrm{M}$, dantrolene decreased (by $39 \pm$ $12 \%)(P<0.01$, vs LPS plus IFN- $\gamma$ alone $)$ the iNOS protein expression in pulmonary alveolar macrophages which were stimulated by LPS plus IFN- $\gamma$.

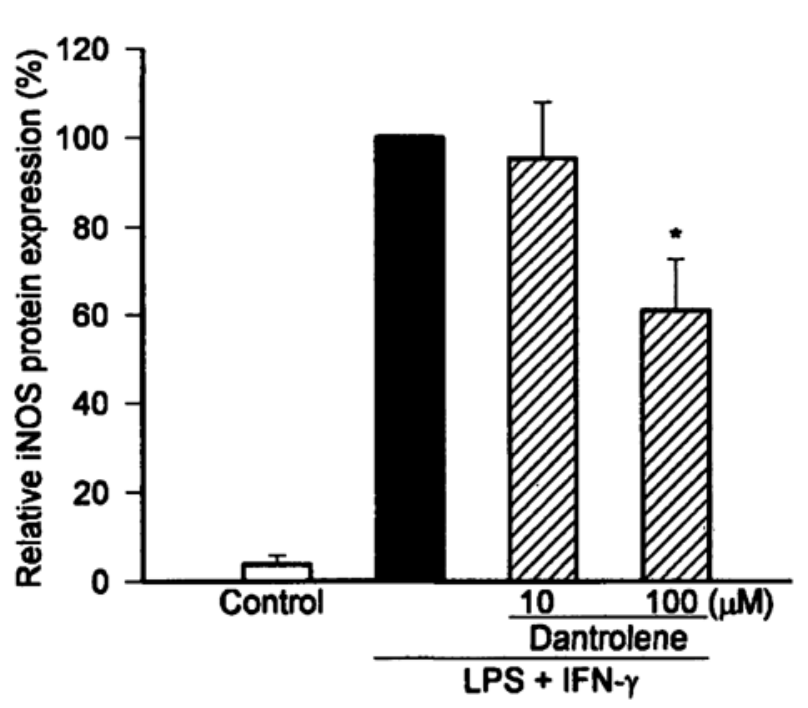

FIGURE 3 Effects of dantrolene on iNOS activity in the rat alveolar macrophages stimulated by LPS plus IFN- $\gamma$. Calcium-independent iNOS activity was measured in the supernatant of macrophages un-treated with LPS plus IFN- $\gamma$ (control; $n=3$ ), treated with LPS $\left(1 \mu \mathrm{g} \cdot \mathrm{ml}^{-1}\right)$ plus IFN- $\gamma\left(100 \mathrm{u} \cdot \mathrm{ml}^{-1}\right)(\mathrm{LPS} ; \mathrm{n}=3)$ or co-treated with LPS plus IFN $-\gamma$ and dantrolene $(10,100 \mu M)(n=3)$ for $24 \mathrm{hr}$.

${ }^{*} P<0.01$ vs LPS plus IFN- $\gamma$ alone.

Note that iNOS activity induced by LPS plus IFN- $\gamma$ was increased when compared with the control. 


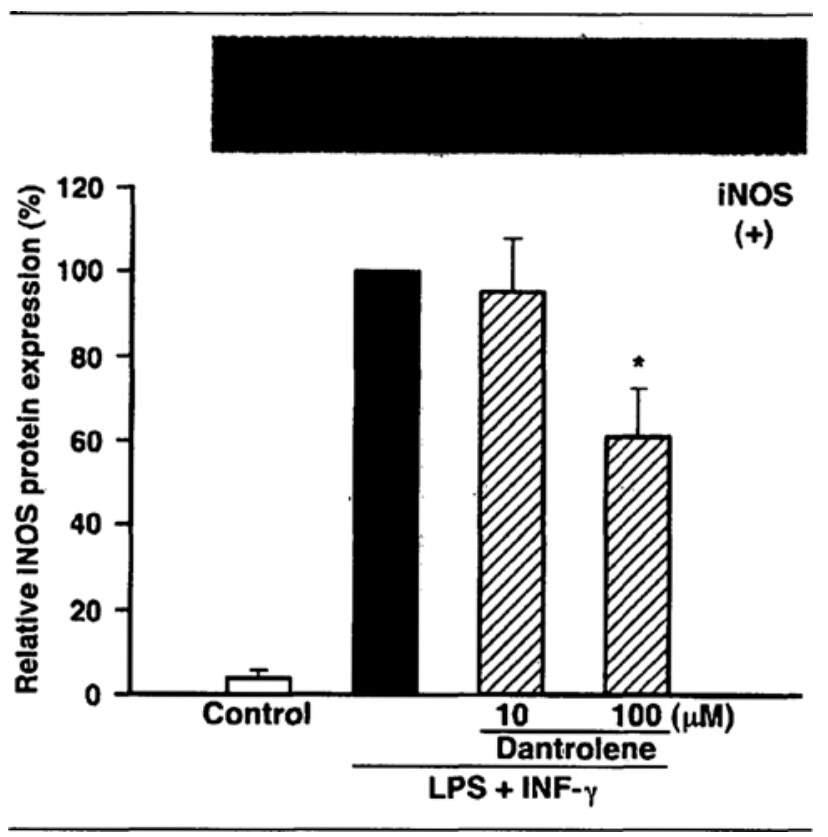

FIGURE 4 Effects of dantrolene on the iNOS protein content in the supernatant of rat alveolar macrophages stimulated by LPS plus IFN- $\gamma$. The expression of iNOS was measured in macrophages untreated with LPS plus IFN- $\gamma$ (control; $n=3$ ), treated with LPS $\left(1 \mu \mathrm{g} \cdot \mathrm{ml}^{-1}\right)$ plus IFN- $\gamma\left(100 \mathrm{u} \cdot \mathrm{ml}^{-1}\right)(\mathrm{n}=3)$ or co-treated with LPS plus IFN- $\gamma$ and dantrolene $(10,100 \mu \mathrm{M})(\mathrm{n}=3)$ for $24 \mathrm{hr}$. The upper panel depicts a representative Western blot, and the lower panel is the statistical summary of the densitometric analysis with the reading from LPS plus IFN- $\gamma$ stimulated macrophages taken as $100 \%$.

${ }^{*} P<0.05$ vs LPS plus IFN- $\gamma$ alone.

\section{Discussion}

In response to LPS and/or cytokines, macrophages produce large amounts of NO, measured as nitrite. This accumulation of nitrite reflects enhanced formation of NO via the induction of iNOS by LPS and cytokines in these cells. In the present study, we first demonstrated that dantrolene, an agent which suppresses the $\mathrm{Ca}^{2+}$ release from the sarcoplasmic reticulum, attenuated the accumulation of nitrite of activated rat alveolar macrophages in a dose-dependent manner. Similar findings had been shown in our previous in vipo study in a rat endotoxin shock model. ${ }^{17}$ Moreover, we demonstrated that dantrolene attenuated the expression of iNOS protein as well as the release of TNF- $\alpha$ levels in cultured macrophages. From these data, we suggest that the reduction of NO formation by dantrolene is due to the inhibition of iNOS induction, which may be associated with a reduction of TNF- $\alpha$ levels.

The mechanism(s), by which dantrolene prevents the induction of iNOS, could be due to inhibition of LPS-stimulated cytokine release and reduction of free cytosolic $\mathrm{Ca}^{2+}$ levels. For instance, after LPS stimulation, dantrolene inhibits TNF- $\alpha$ and interleukin- 1 production in a mouse endotoxaemia model. ${ }^{15,16}$ In addition, several studies have shown that inhibitors of iNOS induction including dexamethasone and dihydropyridine-type calcium channel antagonists were able to suppress the release of TNF- $\alpha$ and the formation of nitrite. ${ }^{11,20,21}$ Consistently, our data also demonstrated that dantrolene dose-dependently inhibited the production of TNF- $\alpha$ and nitrite in cultured alveolar macrophages which were challenged with LPS and IFN- $\gamma$. The results showed that the reduction of TNF- $\alpha$ is, at least in part, associated with the inhibition of iNOS activity and its protein expression by dantrolene in the rat alveolar macrophage.

As for the other possible mechanism that dantrolene could prevent the expression of iNOS by reducing the free cytosolic $\mathrm{Ca}^{2+}$ concentration. Park and his colleagues have demonstrated that a rapid increase of free cytosolic $\mathrm{Ca}^{2+}$ concentrations enhances the induction of iNOS gene expression in murine peritoneal macrophages. ${ }^{6}$ Additionally, in vitro, pretreatment of macrophages with LPS and IFN- $\gamma$ in the presence of calcium ionophore causes an increase of NO production, suggesting that the expression of iNOS is regulated by calcium. ${ }^{22-24}$ Here, we demonstrated that co-treatment of macrophages with dantrolene and LPS plus IFN- $\gamma$ prevented the expression of iNOS. Thus, calcium may be important for the induction of iNOS in macrophages stimulated with LPS plus IFN- $\gamma$. We propose that dantrolene decreases the intracellular calcium level then prevents the expression of iNOS or it indirectly decreases the TNF- $\alpha$ level which consequently attenuates the expression of iNOS. However, the effects of dantrolene on intracellular calcium concentration related to NO production in activated macrophages need to be further investigated.

Before the assessment of the clinical relevance of our results, the following points must be considered. First, calcium is an important modulator of the cellular response occurring during endotoxaemia and sepsis. For example, Song $e t$ al. suggested that sustained increase in intracellular calcium in sepsis may be partially responsible for initiation and perpetuation of organ dusfunction. ${ }^{13}$ Administration of $\mathrm{Ca}^{2+}$ causes high mortality in rats with endotoxic shock..$^{25,26}$ In addition, drugs which act by decreasing intracellular free calcium concentration can improve the survival and prevent metabolic abnormalities in animal models of sepsis/endotoxaemia. ${ }^{9-11}$ Second, cytokines are believed to be important mediators of the inflammatory response occurring in sepsis and endotoxaemia, 
since many studies have shown that therapy aimed at inhibiting the effects of cytokines can also improve the survival in animal models of endotoxaemia. ${ }^{27-29}$ Dantrolene, an agent that reduces free cytosolic $\mathrm{Ca}^{2+}$ and acts on a variety of cell types, has beneficial haemodynamic effects on rats with endotoxaemia and improves the survival in a murine model of severe septic shock. ${ }^{17}$ Most notably the doses of dantrolene used in patients are higher $\left(2-5 \mathrm{mg} \cdot \mathrm{kg}^{-1}\right)$ than that used in our previous study $\left(1 \mathrm{mg} \cdot \mathrm{kg}^{-1}\right)^{17}$ suggesting that this agent may be useful to prevent the expression of iNOS in human. Dantrolene also prevents the release of cytokines (i.e., TNF- $\alpha$ ) in macrophages stimulated with LPS and IFN- $\gamma$, providing that the reduction of TNF- $\alpha$ release by dantrolene is, in part, associated with its beneficial effects in sepsis. Although results from both views are quiet convincing, further clinical studies need to be performed. In addition, in the treatment of sepsis in view of its price and its side effects should also be evaluated.

In conclusion, this study, conducted on isolated rat alveolar macrophages, demonstrated that dantrolene produced a moderate inhibitory effect on the NO and TNF- $\alpha$ production as well as the iNOS expression which was induced by LPS and IFN $-\gamma$.

\section{Acknowledgments}

This work was supported by a grant of the Tri-Service General Hospital, Taipei, Taiwan, R.O.C. (TSGHC87-49). The authors are grateful to Ms. Shu-Chuan Lin for her skilful technical assistance.

\section{References}

1 Moncada S, Palmer RMJ, Higgs EA. Nitric oxide physiology, pathophysiology, and pharmacology. Pharmacol Rev 1991; 43: 109-42.

2 Förstermann U, Schmidt HHHW, Pollock JS, et al. Isoforms of nitric oxide synthase. Characterization and purification from different cell types. Biochem Pharmacol 1991; 42: 1849-57.

3 Xie Q-VV, Cho HJ, Calaycay J, et al. Cloning and characterization of inducible nitric oxide synthase from mouse macrophages. Science 1992; 256: 225-8.

4 Ding AH, Nathan CF, Stuehr DJ. Release of reactive nitrogen intermediates and reactive oxygen intermediates from mouse peritoneal macrophages. Comparison of activating cytokines and evidence for independent production. J Immunol 1988; 141: 2407-12.

5 Geller DA, Lowenstein CJ, Shapiro RA, et al. Molccular cloning and expression of inducible nitric oxide synthase from human hepatocytes. Proc Natl Acad Sci 1993; 90 : 3491-5.

6 Nathan CF, Hibbs JB Jr. Role of nitric oxide synthesis in macrophage antimicrobial activity. Curr Opin Immunol 1991; 3: 65-70.

7 Szabó C, Mitcbell JA, Thiemermann C, Vane JR. Nitric oxide-mediated hyporeactivity to noradrenaline precedes the induction of nitric oxide synthase in endotoxin shock. Br J Pharmacol 1993; 108: 786-92.

8 Park YC, Jun CD, Kang HS, Kin HD, Kim HM, Chung HT. Intracellular $\mathrm{Ca}^{2+}$ pool depletion is linked to the induction of nitric oxide synthesis in murine peritoneal macrophages. Biochem Mol Biol Int 1995; 36: 949-55.

9 Bosson S, Kuenzig M, Schwartz SI. Verapamil improves cardiac function and increases survival in canine E. cold endotoxin shock. Circ Shock 1985; 16: 307-16.

10 Lee HC, Lum BKB. Protective action of calcium entry blockers in endotoxin shock. Circ Shock 1986; 18: 193-203.

11 Szabó C, Mitchell JA, Gross SS, Thiemermann C, Vane $J R$. Nifedipine inhibits the induction of nitric oxide synthase by bacterial lipopolysaccharide. J Pharmacol Exp Ther 1993; 265: 674-80.

12 Ward A, Chaffman MO, Sorkin EM. Dantrolene. A review of its pharmacodynamic and pharmacokinetic properties and therapeutic use in malignant hyperthermia, the neuroleptic malignant syndrome and an update of its use in muscle spasticity. Drugs 1986; 32 : 130-68.

13 HainautK, Desmedt JE. Effect of dantrolene sodium on calcium movements in single muscle fibres. Nature $1974 ; 252: 728-9$.

14 Van Winkle WB. Calcium release from skeletal muscle sarcoplasmic reticulum: site of action of dantrolene sodium? Science 1976; 193: 1130-1.

15 Song S-K, Karl IE, Ackerman JJH, Hotchkiss RS. Increased intracellular $\mathrm{Ca}^{2+}$ : a critical link in the pathophysiology of sepsis? Proc Natl Acad Sci USA 1993; 90: 3933-7.

16 Hotchkiss RS, Karl IE. Dantrolene ameliorates the metabolic hallmarks of sepsis in rats and improves survival in a mouse model of endotoxemia. Proc Natl Acad Sci USA 1994; 91: 3039-43.

$17 W u C \cdot C, Y_{e n} M-H$. Beneficial effects of dantrolene on lipopolysaccharide-induced haemodynamic alternations in rats and mortality in mice. Eur J Pharmocol 1997; 327: 17-24.

18 Li C- , Chou T-C, Wong C-S, et al. Ketamine inhibits nitric oxide synthase in lipopolysaccharide-treated rat alveolar macrophages. Can J Anaesth 1997; 44: 989-95. 
19 Gross SS, Levi R. Tetrabydrobiopterin synthesis. An absolute requirement for cytokine-induced nitric oxide generation by vascular smooth muscle. J Biol Chem 1992; 267: 25722-9.

20 Waage $A$. Production and clearance of tumor necrosis factor in rats exposed to endotoxin and dexamethasone. Clin Immunol Immunopathol 1987; 45: 348-55.

21 Zuckerman SH, Stellhaas J, Butler LD. Differential regulation of lipopolysacharide-induced interleukin- 1 and tumor necrosis factor synthesis: effects of endogenous and exogenous glucocorticoids and the role of the pituitary-adrenal axis. Eur J Immunol 1989; 19: 301-5.

22 Hattori $\Upsilon$, Kasai $K$, So S, Hattori S, Banba N, Shimoda $S$ - $I$. Effects of calcium channel antagonists on the induction of nitric oxide synthase in cultured cells by immunostimulants. Life Sci 1995; 57: 1833-40.

23 Lo C-J, Garcia I, Cryer G, Maier RV. Calcium and calmodulin regulate lipopolysaccharide-induced alveolar macrophage production of tumor necrosis factor and procoagulant activity. Arch surg 1996; 131: 44-50.

24 Denlinger LC, Fisette $P L$, Garis $K A$, et al. Regulation of inducible nitric oxide synthase expression by macrophage purinoreceptors and calcium. J Biol Chem 1996; 271: 337-42.

25 Malcolm DS, Zaloga GP, Holaday JW. Calcium administration increases the mortality of endotoxic shock in rats. Crit Care Med 1989; 17: 900-3.

26 Zaloga GP, Sager A, Black RW, Prielipp R. Low dose calcium administration increases mortality during septic peritonitis in rats. Circ Shock 1992; 37: 226-9.

27 Pinsky MR, Vincent J-L, Deviere J. Serum cytokine levels in human septic shock. Relation to multiple-system organ failure and mortality. Chest 1993; 103: 565-75.

28 Fisher CJ Jr, Opal SM, Dhainaut J-F, et al. Influence of an anti-tumor necrosis factor monoclonal antibody on cytokine level in patients with sepsis. Crit Care Med 1993; 21: 318-27.

29 Hotchliss RS, Osborne DF, Lappas GD, Karl IE.

Calcium antagonists decrease plasma and tissue concentrations of tumor necrosis factor- $\alpha$, interleukin- $1 \beta$, and interleukin-1 $\alpha$ in a mouse model of endotoxin. Shock 1995; 3: 337-42. 